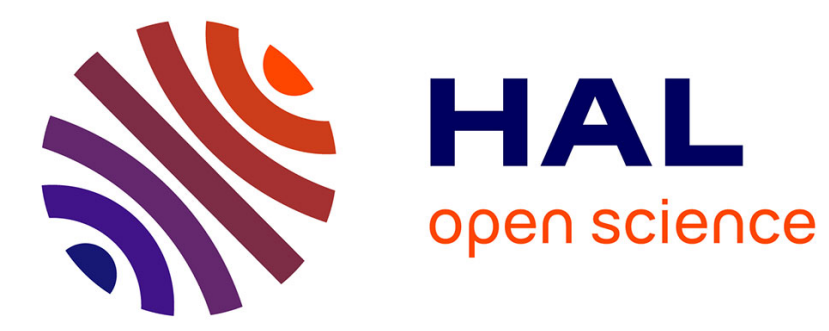

\title{
Precocious maturation and smoltification in wild atlantic salmon in the Armorican Massif France
}

Jean-Luc J.-L. Baglinière, Gérard Maisse

\section{To cite this version:}

Jean-Luc J.-L. Baglinière, Gérard Maisse. Precocious maturation and smoltification in wild atlantic salmon in the Armorican Massif France. Aquaculture, 1985, 45, pp.249-263. 10.1016/00448486(85)90274-1 . hal-02728720

\section{HAL Id: hal-02728720 \\ https://hal.inrae.fr/hal-02728720}

Submitted on 2 Jun 2020

HAL is a multi-disciplinary open access archive for the deposit and dissemination of scientific research documents, whether they are published or not. The documents may come from teaching and research institutions in France or abroad, or from public or private research centers.
L'archive ouverte pluridisciplinaire HAL, est destinée au dépôt et à la diffusion de documents scientifiques de niveau recherche, publiés ou non, émanant des établissements d'enseignement et de recherche français ou étrangers, des laboratoires publics ou privés.

\section{다(1)(2)}

Distributed under a Creative Commons Attribution - ShareAlikel 4.0 International 


\title{
PRECOCIOUS MATURATION AND SMOLTIFICATION IN WILD ATLANTIC SALMON IN THE ARMORICAN MASSIF, FRANCE
}

\author{
J.L. BAGLINIERE ${ }^{1}$ and G. MAISSE ${ }^{2}$ \\ ${ }^{1}$ Laboratoire d'Ecologie Hydrobiologique, and ${ }^{2}$ Laboratoire de Physiologie des Poissons, \\ I.N.R.A., 35042 Rennes Cédex (France)
}

\begin{abstract}
Baglinière, J.L. and Maisse, G., 1985. Precocious maturation and smoltification in wild Atlantic salmon in the Armorican massif, France. Aquaculture, 45: 249-263.

In wild Atlantic salmon, Salmo salar, of Armorican rivers, precocious maturity occurred at $<5 \%$ at age $0+$ (males only). At $1+$ (in both sexes) the percentage occurrence varied between years and stretches of river. Spawning marks on scales of smolts and anadromous adults confirmed that such fish smoltify after spawning. From back-calculation from scales of $R$. Scorff salmon it was found that: (1) mature parr were larger than immature fish at $1+$ in autumn and at smolting; (2) mature $1+$ parr had been intermediate in length between upper and lower modal group fish in their first autumn. It is suggested that in western France a holobiotic cycle for the Atlantic salmon can occur before the amphibiotic one as an adaptive strategy.
\end{abstract}

\section{INTRODUCTION}

Precocious sexual maturation of wild Atlantic salmon parr (Salmo salar) occurs frequently in males (Shaw, 1836; Bouisset, 1928; Orton et al., 1938; Vibert, 1950; Osterdahl, 1969; Mitans, 1973; Lee and Power, 1976; Buck and Youngson, 1982; Dalley et al., 1983), but has not often been observed in females (Regan, 1938; Prouzet, 1981; Baglinière et al., 1981). Parr sperm is of good quality (Bouisset, 1928; Jones and King, 1952; Jones, 1959; Thorpe and Morgan, 1980; Kazakov, 1981): the quality of ova has been studied in only one female in which 50\% were fertile (Prouzet, 1981). Jones and King (1949) showed that mature male parr took part in natural spawning, and most authors agree that such parr may subsequently smoltify. By comparing sex ratios in smolts and migrant adults Mitans (1973) showed similar survival of mature and immature male smolts to adult return. Thorpe and Morgan (1980) verified through tagging that spent male smolts grew normally at sea and returned as adults. Saunders et al. (1982) reported that previously mature parr developed similar tolerance to high salinities (35-40 ppt), $\mathrm{Na}^{+}-\mathrm{K}^{+}$-ATPase activities, and thyroid hormone content as immature smolts.

In the Armorican rivers of N.W. France we have found ripe male parr in 
autumn, and spent parr and smolts the following spring. We have recently reported on spawning marks on scales of parr, smolts and migrant adults from these rivers (Maisse and Baglinière, 1983). The present paper concerns the growth of these precocious fish.

\section{MATERIAL AND METHODS}

\section{Rivers}

The physical characteristics of the Armorican rivers have been described by Fontenelle et al. (1980). At latitudes $48.5-49^{\circ} \mathrm{N}$, and projecting into the Atlantic Ocean, the area has a maritime climate without temperature extremes.

Fish

Most Armorican salmon smolts migrate at 1 year old (Fontenelle et al., 1980 ), but proportions of 1 - and 2-year-olds vary annually and locally (Baglinière, 1976; Prouzet and Jezequel, 1983). Four kinds of fish were studied:

(1) parr electrofished from the rivers Scorff and Trieux in October 19801983;

(2) smolts trapped on downstream migration in a tributary of the Scorff, in 1982-1983 (these had migrated upstream with adults the previous winter);

(3) smolts trapped in R. Elle in 1972-1973;

(4) adults which smolted at 2+, angled, trapped, or dying from pollution or after spawning, in 16 rivers of Brittany and Lower Normandy in 1971-1983.

\section{Collection and analysis of data}

Fork lengths were measured, and scales sampled from the area between the lateral line and the dorsal fin. Male parr maturity was defined by expressing milt, while in females maturity was revealed by serological immunoagglutination (Le Bail et al., 1981) and by immunodiffusion (Le Bail and Breton, 1981). Sex of dead or mended kelts was also recorded.

Spawning marks were identified from erosion on the scale surface (Fig. 1). It was assumed that under the relatively favourable growth conditions for salmon in N.W. France, only spawning could account for the resorption of material from scales, so producing the discontinuities of circuli (Backiel and Sych, 1958; White and Medcof, 1968). Such marks were investigated on four scales of each fish, and, if occurring on two of them, were considered evidence of a spawning.

Back-calculations were made using a linear relationship of the form: body-length $\left(L_{\mathrm{f}}\right)=(a+b) \cdot$ scale-length $\left(L_{\mathrm{e}}\right)$, from which lengths of $1+$ parr 


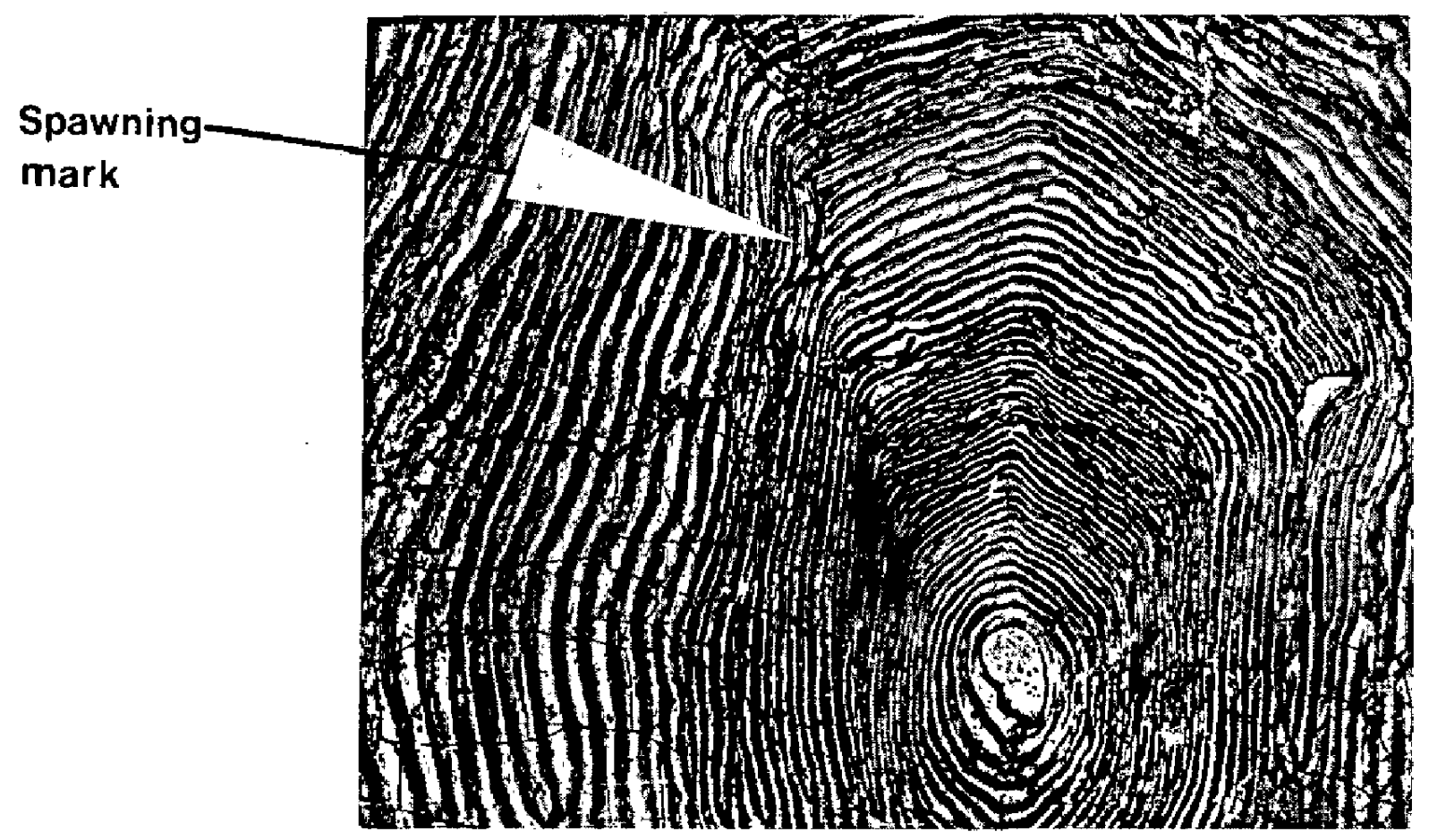

Fig. 1. Atlantic salmon scale, showing spawning mark at age 2 (maturity at parr stage).

at the end of their first winter were calculated. In adults, smolt length was back-calculated from length proportionality of fish-length/scale-length at the smolt stage. To estimate parr size of these fish in their first and second winters, the body $\rightarrow$ scale relationship calculated from the corresponding parr cohorts was used. The autumn and first winter growth of parr was estimated from the number of appropriate days for growth, i.e. those during which the average temperature was $\geqslant 7{ }^{\circ} \mathrm{C}$ (Allen, 1941; Egglishaw and Shackley, 1977; Brett, 1979; Symons, 1979). Instantaneous growth rate was calculated using: $G=100\left(\log L_{2}-\log L_{1}\right) / \Delta T$, where $\Delta T$ represents the number of appropriate days. Based on our observations and those of Pedley and Jones (1978), $G$ was calculated to be 0.1 . By using such back-calculated values, and values for winter growth, we have been able to determine the length of $1+$ parr in their first autumn.

\section{RESULTS}

\section{Importance of precocious maturation}

Mature male parr are rare at $0+(4.2$ and $6.4 \%$ in 1983 on the Scorff and Trieux rivers, respectively). At $1+$ male precocity varies annually and between rivers (Scorff: 0-43.5\%; Trieux: 0-100\%). Some mature 1+females have been recorded in the Scorff. Spawning marks have been found on eight parr at $2+$, one at $3+$ (two spawnings), and one at $4+$ (three spawnings). In the River Elle, $22 \%$ of 2+ smolts had spawning marks, but of 14 known mature male smolts only 9 had spawning marks. 
Among anadromous adults angled, 99 out of 678 (17.5\%) had spawning marks. More 2-sea-year salmon (15\%) showed spawning marks than did grilse $(6 \%)(P<0.05)$, but there were no significant differences between 2 - and 3 -sea-year fish, or between rivers (Table I). More males (17\%) had spawning marks than did females $(6 \%)(P<0.05)$ : this effect is evident chiefly in $2-$ sea-year salmon $(P<0.02)$ and only in the S. Brittany rivers, Scorff, Blavet and Elle $(P<0.01)$ (Table II).

\section{TABLE I}

Adult Atlantic salmon showing spawning marks on the scales in the second freshwater winter

\begin{tabular}{|c|c|c|c|c|c|c|}
\hline \multirow[t]{3}{*}{ River } & \multicolumn{6}{|c|}{ Sea age } \\
\hline & \multicolumn{2}{|l|}{$\mathbf{I}$} & \multicolumn{2}{|l|}{ II } & \multicolumn{2}{|l|}{ III } \\
\hline & $n$ & SM & $n$ & SM & $\bar{n}$ & $\mathbf{S M}$ \\
\hline Scorff & 18 & 0 & 138 & $\begin{array}{l}21 \\
(15 \%)\end{array}$ & 12 & 2 \\
\hline Ellé & 38 & 2 & 121 & $\begin{array}{l}23 \\
(19 \%)\end{array}$ & 20 & 4 \\
\hline \multicolumn{7}{|l|}{ Other rivers in } \\
\hline South Brittany & 3 & 0 & 50 & 8 & 1 & 1 \\
\hline Elorn & 3 & 1 & 143 & $\begin{array}{l}17 \\
(12 \%)\end{array}$ & 10 & 0 \\
\hline \multirow{2}{*}{$\begin{array}{l}\text { Other rivers in } \\
\text { North Brittany }\end{array}$} & & & & & & \\
\hline & 3 & 1 & 58 & 10 & 1 & 0 \\
\hline \multicolumn{7}{|l|}{ Rivers of Lower } \\
\hline Normandy & 0 & 0 & 56 & 9 & 3 & 0 \\
\hline Total & 65 & $\begin{array}{c}4 \\
(6 \%)\end{array}$ & 566 & $\begin{array}{l}88 \\
(15 \%)\end{array}$ & 47 & $\begin{array}{c}7 \\
(15 \%)\end{array}$ \\
\hline
\end{tabular}

$n$ : total number of observed fishes.

SM: number of individuals with a spawning mark.

Characteristics of precocious individuals

At $0+$ precocity appears in both modes of the length frequency distribution (Table III). At $1+$ in autumn in the Scorff, mature individuals were larger than immatures (Table IV), and from back-calculation it was found that they had been so in the previous autumn when they were found in the upper rather than the lower mode (Table V). In 1983 ripe males in the Trieux were much larger $(176 \mathrm{~mm})$ than in the Scorff $(139 \mathrm{~mm})$. 
TABLE II

Adult Atlantic salmon showing spawning marks on the scales in the second freshwater winter

\begin{tabular}{|c|c|c|c|c|c|}
\hline \multirow[t]{2}{*}{ River } & \multirow[t]{2}{*}{ Sea age } & \multicolumn{2}{|c|}{ Male } & \multicolumn{2}{|c|}{ Female } \\
\hline & & $n$ & SM & $n$ & SM \\
\hline \multirow{4}{*}{$\overline{\text { Elorn }}$} & I & 1 & 0 & 3. & 1 \\
\hline & II & 27 & 4 & 82 & 6 \\
\hline & III & 2 & 0 & 6 & 0 \\
\hline & Total & 30 & 4 & 91 & 7 \\
\hline \multirow{4}{*}{ Ellé } & $I$ & 8 & 1 & 20 & 0 \\
\hline & II & 6 & 4 & 19 & 0 \\
\hline & III & 0 & 0 & 5 & 0 \\
\hline & Total & 14 & 5 & 44 & 0 \\
\hline \multirow[t]{4}{*}{ Scorff and Blavet } & $\mathbf{I}$ & 14 & 1 & 12 & 0 \\
\hline & II & 10 & 1 & 19 & 3 \\
\hline & III & 2 & 1 & 1 & 0 \\
\hline & Total & 26 & 3 & 32 & 3 \\
\hline \multirow[t]{4}{*}{ Total } & I & 23 & 2 & 35 & 1 \\
\hline & II & 43 & 9 & 120 & 9 \\
\hline & III & 4 & 1 & 12 & 0 \\
\hline & Total & 70 & $\begin{array}{l}12 \\
17 \%\end{array}$ & 167 & $\begin{array}{l}10 \\
6 \%\end{array}$ \\
\hline
\end{tabular}

$n:$ total number of observed fishes.

SM: number of individuals with a spawning mark.

\section{TABLE III}

Characteristics of mature $0+$ males observed in autumn in two Brittany rivers (Scorff and Trieux)

\begin{tabular}{|c|c|c|c|c|c|c|c|c|}
\hline \multirow[t]{2}{*}{$\overline{\text { River }}$} & \multirow[t]{2}{*}{$\%$ in $0+$} & \multirow{2}{*}{$\begin{array}{l}\text { Length } \\
(\mathrm{mm})\end{array}$} & \multicolumn{3}{|c|}{ Low mode } & \multicolumn{3}{|c|}{ Upper mode } \\
\hline & & & $\bar{l}$ & $n$ & SD & $\bar{l}$ & $n$ & SD \\
\hline $\begin{array}{l}\text { Scorff (lower } \\
\text { course) }\end{array}$ & 4.2 & $89-100-120$ & 84 & 14 & 2.4 & 102 & 58 & 5.8 \\
\hline Trieux & 6.4 & $103-130$ & 98 & 13 & 6.9 & 123 & 18 & 6.0 \\
\hline
\end{tabular}

$\vec{l}$ : mean length (mm). $n$ : number, SD: standard deviation.. 


\section{TABLE IV}

Characteristics of $1+$ parr in autumn in the River Scorff

\begin{tabular}{|c|c|c|c|c|c|c|c|c|}
\hline \multirow[t]{3}{*}{ Year } & \multirow{2}{*}{\multicolumn{3}{|c|}{$\begin{array}{l}\text { Immature } \\
\text { mean length }(\mathrm{mm})\end{array}$}} & \multicolumn{4}{|c|}{ Mature } & \multirow{3}{*}{$\begin{array}{l}\text { Significance } \\
\text { of differences } \\
\text { between lengths }\end{array}$} \\
\hline & & & & \multicolumn{3}{|c|}{ mean length $(\mathrm{mm})$} & \multirow{2}{*}{$\begin{array}{l}\text { percentage } \\
\text { in the } \\
\text { population }\end{array}$} & \\
\hline & $n$ & & SD & $n$ & & SD & & \\
\hline \multirow{5}{*}{$\begin{array}{l}1980 \\
1981 \\
1982 \\
\text { (lower part only) } \\
1983 \\
\text { (upper part only) }\end{array}$} & 50 & 150 & 17.3 & 5 & 179 & 19.2 & 9.1 & $* *$ \\
\hline & 13 & 132 & 15.0 & 10 & 154 & 18.1 & 43.5 & $* *$ \\
\hline & 32 & 146 & 10.6 & 15 & $152^{\mathrm{a}}$ & 15.2 & 0 & NS \\
\hline & 24 & 151 & 13.1 & 17 & 158 & 16.9 & 41.5 & NS \\
\hline & 74 & 125 & 8.7 & 35 & 130 & 11.7 & 32.1 & * \\
\hline
\end{tabular}

${ }^{a}$ Mean back-calculated length (in the second winter in fresh water) of parr and smolts caught by trapping on the Kernec stream.

$n$ : number. SD: standard deviation. $* P<0.05 . * * P<0.01$.

Most mature female parr in the Scorff were 1+ and large (Table VI). From back-calculation it was found that they came originally from the lower mode at 0+. Relative fecundities for two fish were 1370 and 1750 oocytes/ $\mathrm{kg}$ respectively, with mean oocyte diameter of $2.7 \mathrm{~mm}$ (Le Bail, pers. commun., 1984).

From back-calculations from adults in the Scorff in 1970-1983, spent smolts were found to be significantly larger than immatures $(P<0.05$; Table VII). However, this difference is not seen among smolts caught on migration down the Elle in 1973.

Finally, by back-calculation from Scorff material from 1970-1983, fish which matured before smolting at $2+$ were found to be significantly larger at the end of both their first and second winters in fresh water than were the immature fish (Table VIII). (The small number of individuals with spawning marks has necessitated the pooling of data, and so no year-to-year variations can be calculated.)

\section{DISCUSSION}

\section{Interpretation of spawning marks}

The distinctness of the spawning mark depends on the extent of marginal erosion at spawning time, and on the following new period of growth. The presence of the mark may thus depend on the spawning period, and the time between spawning and capture. Also, the formation of the mark may depend on climatic conditions, which fluctuate greatly in Brittany: in 19801981 there were only 41 winter days with temperatures above $7^{\circ} \mathrm{C}$, compared with 143 the following winter. Southern (1933) noted that in some 


\section{TABLE V}

Parr from River Scorff in autumn. Mean back-estimated length (in the first winter in fresh water) and probability of belonging to the lower modal group at $0+$

\begin{tabular}{|c|c|c|c|c|c|c|c|c|c|c|c|c|c|c|}
\hline \multirow[t]{3}{*}{ Year } & \multicolumn{6}{|c|}{ Mean length of the whole $0+$ population $(\mathrm{mm})^{\mathrm{a}}$} & \multicolumn{4}{|c|}{ Immature parr } & \multicolumn{4}{|c|}{ Mature parr } \\
\hline & \multicolumn{3}{|c|}{ Lower mode } & \multicolumn{3}{|c|}{ Upper mode } & \multicolumn{3}{|c|}{ Mean length } & \multirow[t]{2}{*}{$\overline{\text { Probability }}$} & \multicolumn{3}{|c|}{ Mean length } & \multirow[t]{2}{*}{ Probability } \\
\hline & $n$ & $(\mathrm{~mm})$ & $\mathrm{SD}$ & $n$ & $(\mathrm{~mm})$ & SD & $n$ & $(\mathrm{~mm})$ & $\mathrm{SD}$ & & $n$ & $(\mathrm{~mm})$ & $\mathrm{SD}$ & \\
\hline 1980 & 40 & 92 & 7.0 & 55 & 102 & 6.2 & 4 & 85 & 12.8 & 84 & 5 & 103 & 18.5 & 39 \\
\hline $\begin{array}{l}1981 \\
1982\end{array}$ & 47 & 84 & 7.8 & 47 & 97 & 8.2 & 30 & 87 & 9.2 & 63 & 15 & 97 & 17.1 & 34 \\
\hline (lower part only) & 31 & 84 & 7.4 & 57 & 97 & 8.2 & 20 & 85 & 7.9 & 73 & 13 & 95 & 14.2 & 35 \\
\hline (upper part only) & 84 & 72 & 6.5 & 92 & 86 & 6.2 & 67 & 75 & 5.6 & 67 & 34 & 80 & 5.9 & 55 \\
\hline
\end{tabular}

${ }^{\mathrm{a}}$ Length estimated by the Battacharya method (Baglinière and Champigneulle, unpublished data).

$n$ : number. $\mathrm{SD}$ : standard deviation. 


\section{TABLE VI}

Characteristics of mature female parr: River Scorff

\begin{tabular}{|c|c|c|c|c|c|c|c|c|c|c|c|c|}
\hline \multirow[t]{4}{*}{ Catch month } & \multirow{4}{*}{$\begin{array}{l}\text { Length } \\
(\mathrm{mm})\end{array}$} & \multirow[t]{4}{*}{ Age } & \multirow{2}{*}{\multicolumn{6}{|c|}{$\begin{array}{l}\text { Mean length of the } \\
\text { whole } 0+\text { population }(\mathrm{mm})\end{array}$}} & \multirow[t]{4}{*}{ Probability $^{a}$} & \multirow{4}{*}{$\begin{array}{l}\text { Gonadosomatic } \\
\text { index }\end{array}$} & \multicolumn{2}{|l|}{ Fecundity } \\
\hline & & & & & & & & & & & \multirow{3}{*}{$\begin{array}{l}\text { Absolute } \\
\text { number of } \\
\text { oocytes }\end{array}$} & \multirow{3}{*}{$\begin{array}{l}\text { Relative } \\
\text { number of } \\
\text { oocytes } / \mathrm{kg}\end{array}$} \\
\hline & & & \multicolumn{3}{|c|}{ Lower mode } & \multicolumn{3}{|c|}{ Upper mode } & & & & \\
\hline & & & $n$ & $(\mathrm{~mm})$ & $\overline{\mathrm{SD}}$ & $n$ & $(\mathrm{~mm})$ & SD & & & & \\
\hline October 1980 & 211 & $1+$ & 6 & 95 & 3.3 & 14 & 120 & 8.2 & Upper modal & - & 158 & 1370 \\
\hline August 1982 & $\begin{array}{l}164 \\
150 \\
175 \\
170\end{array}$ & $\begin{array}{l}1+ \\
1+ \\
1+ \\
1+\end{array}$ & 40 & 94 & 6.0 & 76 & 116 & 7.0 & $\begin{array}{l}94 \% \\
\text { in the lower } \\
\text { modal group }\end{array}$ & $\begin{array}{l}2.6 \\
3.6 \\
3.3 \\
4.4\end{array}$ & & \\
\hline October 1983 & 192 & $2+$ & 44 & 82 & 5.7 & 30 & 92 & 5.0 & $\begin{array}{l}\text { Lower modal } \\
\text { group }\end{array}$ & - & 163 & 1750 \\
\hline
\end{tabular}

a Probability of belonging to a particular modal group when $0+$.

$n$ : number. SD: standard deviation. 
TABLE VII

Characteristics of $2+$ smolts: Rivers Elle and Scorff

\begin{tabular}{|c|c|c|c|c|c|c|c|}
\hline & \multicolumn{3}{|c|}{ Fish with spawning marks } & \multicolumn{3}{|c|}{ Fish without spawning marks } & \multirow{2}{*}{$\begin{array}{l}\text { Significance } \\
\text { of difference } \\
\text { between lengths }\end{array}$} \\
\hline & $\begin{array}{l}\text { Mean } \\
\text { length } \\
(\mathrm{mm})\end{array}$ & Number & $\begin{array}{l}\text { Standard } \\
\text { deviation }\end{array}$ & $\begin{array}{l}\text { Mean } \\
\text { length } \\
\text { (mm) }\end{array}$ & Number & $\begin{array}{l}\text { Standard } \\
\text { deviation }\end{array}$ & \\
\hline $\begin{array}{l}\text { River Elle } \\
1973 \\
\text { observed lengths }\end{array}$ & 190 & 32 & 16.5 & 187 & 113 & 16.9 & NS \\
\hline $\begin{array}{l}\text { River Scorff } \\
1972-1983 \\
\text { back-calculated } \\
\text { lengths }\end{array}$ & 210 & 29 & 32.5 & 190 & 113 & 27.5 & $P<0.01$ \\
\hline
\end{tabular}

\section{TABLE VIII}

Adult salmon: back-calculated lengths at first $\left(L_{1}\right)$ and second $\left(L_{2}\right)$ winters, River Scorff $1972-1983$

\begin{tabular}{|c|c|c|c|c|c|c|}
\hline & \multicolumn{3}{|l|}{$\underline{L_{1}}$} & \multicolumn{3}{|l|}{$L_{2}$} \\
\hline & $n$ & $(\mathrm{~mm})$ & SD & $n$ & $(\mathrm{~mm})$ & $\mathrm{SD}$ \\
\hline Fish with spawning mark & 14 & 117 & 17.2 & 14 & 197 & 28.4 \\
\hline Fish without spawning mark & 47 & 101 & 17.7 & 47 & 172 & 30.9 \\
\hline $\begin{array}{l}\text { Significance of differences } \\
\text { between lengths }\end{array}$ & \multicolumn{3}{|c|}{$P<0.01$} & \multicolumn{3}{|c|}{$P<0.01$} \\
\hline
\end{tabular}

$n$ : number. SD: standard deviation.

Shannon fish only a small proportion of scales bore spawning marks. As only four scales were examined on each of our fish this may explain our failure to find spawning marks on some mature parr. This technique would then underestimate the numbers of parr which had matured.

\section{Incidence of maturation}

o+ male parr. Precocious sexual maturation at $0+$ has occasionally been observed in the wild. Jones (1949) reported seven spent males among $931+$ smolts on the River Dee, and Vibert (1950) found two spent males among $451+$ smolts on the River Adour. Such observations are infrequent in the natural environment and concern males only.

Maturation of 0+ male parr has occurred in rearing experiments in Canada (Bailey et al., 1980), where the proportion varied from 2 to $38 \%$ according to family. The presence of mature males appears to be related to favourable growing conditions. This confirms the results from the Scorff in particular, 

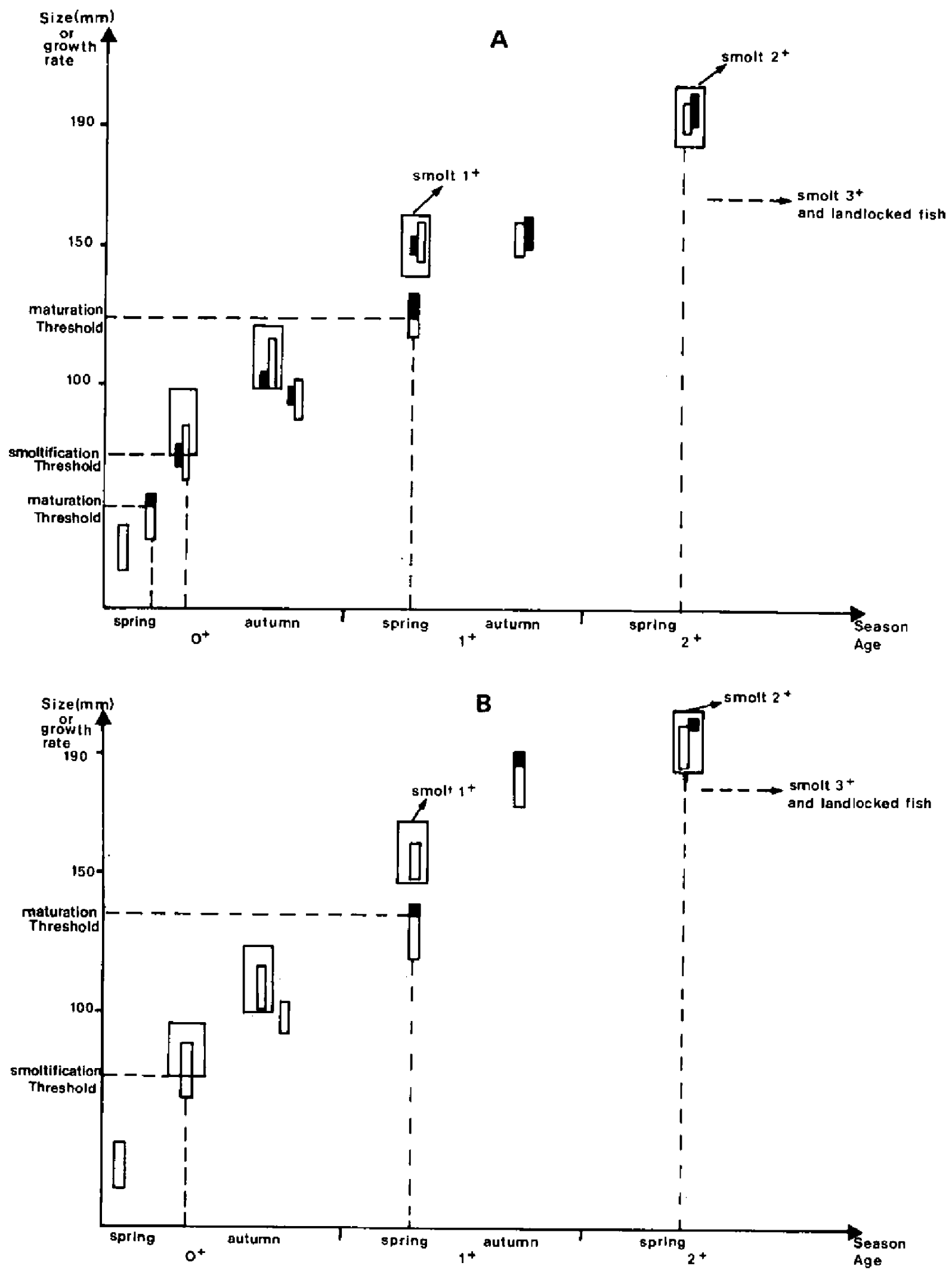
where growth rate was high, and $0+$ fish had mean lengths equal to or greater than those of $1+$ fish in Scotland (Egglishaw and Shackley, 1977). Moreover, precocious sexual maturation at the $0+$ stage has been found only in the lower course of the river where growth rate was always higher (Baglinière and Dhorne, unpubl.).

The quantitative importance of maturation at $0+$ is difficult to evaluate on the basis of only one year's observations, in two rivers, and only on the basis of spermiation.

$1+$ male parr. Precocious sexual maturation is generally first observed at $1+$, both in the wild and under rearing conditions. The percentage of precocious males at $1+$ was comparable to published values (40\%, Orton et al., 1938; $75.2 \%$, Mitans, 1973; 40-60\%, Meister (cited in Schaffer and Elson, 1975); 59.7\%, Dalley et al., 1983; and 50\% in hatcheries, Lundqvist, 1983). Most authors agree that fish with faster growth mature first (Leyzerovich, 1973; Mitans, 1973; Knutsson, 1979; Thorpe et al., 1982, 1983). Such was the case on the River Scorff in 1983: maturation was higher downstream where growth rate was higher than upstream. It seems then, that the larger the fish are at $1+$ the more males mature as parr. The segregation between the two groups had already appeared by the previous autumn, as mature parr are more often in the upper mode of the length frequency distribution at age $0+$. In Brittany future mature parr maintained their size advantage until the second autumn, and even until the end of their second winter: other authors (Murphy, 1981; Saunders et al., 1982; Thorpe et al., 1982, 1983; Lundqvist, 1983; Gjerde, 1984) have found reduced growth in mature parr. Only Dalley et al. (1983) noted that ripe 1+ parr were larger than immatures of the same age, but they found a delay in growth among maturing parr at $2+$.

Mature female parr. Mature female parr were not found under rearing conditions (Saunders et al., 1982; Thorpe et al., 1982; Lundqvist, 1983) and only very seldom in nature (Regan, 1938; Tchernavin, 1938). Fontaine and Vibert (1950) reported an hermaphrodite fish caught in the River Adour. More recently, mature female parr have been reported by Mills (1971) in Scotland and by Baglinière et al. (1981) and Prouzet (1981) in Brittany. These individuals could be hybrids between Atlantic salmon and brown trout. How-

Fig. 2. Model of population dynamic strategy in the freshwater phase for Atlantic salmon of Brittany and Lower Normandy. A: males; B: females. Histograms are not to scale. Three points are considered:

(1) a maturation threshold (size) at $0+$ (Bailey et al., 1980); this would be relevant near emergence (Saunders et al., 1982);

(2) a smoltification threshold (size) (Thorpe et al., 1980); this would be relevant in mid. summer (Thorpe et al., 1982) and so later than the maturation threshold in the experiments of Bailey et al. (1980);

(3) a few individuals smolting at $>2+$; most fishes staying in fresh water would be males (Mitans, 1973). 
ever, the morphological characters of such hybrids observed by Solomon and Child (1978) were not evident. Furthermore, the high ova fertility of mature female parr (Prouzet, 1981) does not corroborate the low values reported by Chevassus (1979) for hybrids between these two species. The only mature $2+$ female was caught in the upper part of the River Scorff where growth was slower. It was of the same age but smaller (192 vs 225 $\mathrm{mm}$ ) than that found by Prouzet (1981). The five other 1+ mature females were caught in the lower course of the river in an area of light organic pollution where growth is very fast. The small number of these parr did not allow us to determine their position in the autumn bimodal length distribution. However, they must reach a developmental threshold or a critical size for maturation, accelerating the gonadosomatic ratio cycle (Dodd et al., 1978) and maturing at $1+$ or $2+$ according to growth conditions. Considering the higher energetic cost of production of ovaries than of testes (Thorpe et al., 1982) this maturation threshold must be higher in females.

The calculated relative fecundities fell within those reported by Jarrams (1979) (1091-1786 ova/kg) for Atlantic salmon kept in fresh water.

From these results it is seen that the maturation of female parr is important in Atlantic salmon population dynamics in rivers of Brittany, even if their spawning behaviour and the subsequent development of their progeny are unknown in natural conditions.

Smolts. Our results confirm that some mature individuals smoltify and migrate to sea (Jones, 1949; Vibert, 1950; Mitans, 1973; Thorpe and Morgan, 1980; Saunders et al., 1982). The size advantage of maturing fish decreased at the smolt stage, although back-calculation from adults showed significant size differences between both groups. Growth rate in maturing parr slowed down between the end of the second winter and the smolt stage.

Anadromous adults. Lack of a river effect on the occurrence of spawning marks, and a sex and sea-age effect in favour of males and 2-sea-winter adults was probably due to two causes: inadequate sampling in some rivers of the southwest and north coasts; and the various biological characteristics of different stocks. Only the characteristics of adults caught during the fishing season (March-mid May) are well known (Fontenelle et al., 1980); there is little or no information on autumn runs in which grilse are probably dominant (Porcher and Baglinière, unpubl., 1984). This lack of data for salmon populations of the Armorican chain prevents determination of an objective relationship between precocious maturation and maturation of fish at sea. This relationship is poorly defined elsewhere (Larsson and Svensson, 1974; Naevdal, 1983; Gjerde, 1984). The presence of spawning marks on scales from females confirms that the mature female parr belong to an anadromous salmon population. 


\section{CONCLUSIONS}

Even though the biological differences found in nature between immature and mature male populations may depend on the choice of study technique, maturation itself depends on the wide variability of growth conditions in rivers of Brittany. The present results suggest a strategy for the freshwater phase of Atlantic salmon in these rivers (Fig. 2). In particular, the importance of maturing male parr populations should be noted, as in crosses with adult females the precocity character is heritable (Thorpe et al., 1983; Gjerde, 1984) and likely to have a strong influence on the whole dynamics of the species (Myers, 1983). Also, the occurrence of ripe male and mature female parr shows that a holobiotic cycle may exist, as simultaneous migrations of male and female parr towards spawning grounds have been observed (Prouzet, 1981). This fact strengthens the idea that mature parr provide insurance in the species dynamics (Jones, 1959; Osterdahl, 1969).

\section{ACKNOWLEDGEMENTS}

We thank Mme Sylvie Bourget-Rivoalan, M.P. Prouzet, and M.J.P. Porcher for their help in collecting data; and Mme M. Le Faurichon for translating this paper. Reviews by R.L. Saunders and J.E. Thorpe greatly improved the clarity of presentation of the manuscript.

\section{REFERENCES}

Allen, K.R., 1941. Studies on the biology of the early stages of the salmon (Salmo salar). 3. Growth in the Thurso River system, Caithness. J. Anim. Ecol., 10: 273-295.

Backiel, T. and Sych, R., 1958. Scale resorption and spawning marks in sea trout (Salmo trutta L.) from Polish waters. Rocz. Nauk. Roln., 73: 119-148.

Baglinière, J.L., 1976. Etudes des populations de saumon atlantique (Salmo salar L., 1766) en Bretagne-Basse-Normadie. I. Caracteristique des smolts de la rivière Elle. Ann. Hydrobiol., 7: 141-158.

Baglinière, J.L., Le Bail, P.Y. and Maisse, G., 1981. Detections de femelles de salmonides en vitellognese. 2. Un exemple d'application: recensement dans la population de truite commune (Salmo trutta) d'une rivière de Bretagne Sud (Le Scorff). Bull. Fr. Piscic., 283: 89-95.

Bailey, J.K., Saunders, R.L. and Buzeta, M.I., 1980. Influence of parental smolt age and sea age on growth and smolting of hatchery-reared Atlantic salmon (Salmo salar). Can. J. Fish. Aquat. Sci., 37: 1379-1386.

Bouisset, L., 1928. Maturité sexuelle prococe du saumon (Salmo salar L.). C.R. Soc. Biol., 98: $92-93$.

Brett, J.R., 1979. Environmental factors and growth. In: W.S. Hoar, D.J. Randall and J.R. Brett (Editors), Fish Physiology, Vol. 8. Academic Press, New York and London, pp. 599-667.

Buck, R.G.J. and Youngson, A.F., 1982. The downstream migration of precociously mature Atlantic salmon, Salmo salar, parr in autumn; its relation to the spawning migration of mature adult fish. J. Fish Biol., 20: 279-288.

Chevassus, B., 1979. Hybridisation in salmonids: results and perspectives. Aquaculture, 17: $113-128$. 
Dalley, E.L., Andrews, C.W. and Green, J.M., 1983. Precocious male Atlantic salmon in insular Newfoundland. Can. J. Fish. Aquat. Sci., 40: 647-652.

Dodd, J.M., Stuart-Kregor, P.A.C., Sumpter, J.P., Crim, L.W. and Peter, R.E., 1978. Premature sexual maturation in the Atlantic salmon (Salmo salar L.). In: P.J. Gaillard and H.H. Boer (Editors), Comparative Endocrinology. Elsevier, Amsterdam, pp. 101104.

Egglishaw, H.J. and Shackley, P.E., 1977. Growth, survival and production of juvenile salmon and trout in a Scottish stream, 1966-75. J. Fish Biol., 11:647-678.

Fontaine, M. and Vibert, R., 1950. Sur un parr de saumon hermaphrodite parvenu a maturité sexuelle. J. Cons. Int. Explor. Mer, 16: 215-226.

Fontenelle, G., Douaire, G., Baglinière, J.L., Prouzet, P. and Harache, Y., 1980. Atlantic salmon (Salmo salar L.) in Brittany and Lower Normandy: preliminary observations on the general characteristics of adults. Fish. Manage,, 11: 87-100.

Gjerde, B., 1984. Response to individual selection for age at sexual maturity in Atlantic salmon. Aquaculture, 38: 229-240.

Jarrams, P., 1979. Egg, fry and smolt production from salmon (Salmo salar L.) and sea trout (Salmo trutta L.) reared entirely in freshwater. J. Fish Biol, 15: 607-611.

Jones, J.W., 1949. Studies on scales of young salmon Salmo salar L. (juv.) in relation to growth, migration and spawning. Fish. Invest., $5: 1-23$.

Jones, J.W., 1959. The Salmon. Collins, London, 192 pp.

Jones, J.W. and King, G.M., 1949. Experimental observations on the spawning behaviour of the Atlantic salmon (Salmo salar L.). Proc. Zool. Soc. Lond., 119: 33-48.

Jones, J.W. and King, G.M., 1952. The spawning of the male salmon parr (Salmo salar Linn. juv.). Proc. Zool. Soc. Lond., 122: 615-619.

Kazakov, R.V., 1981. Peculiarities of sperm production by anadromous and parr Atlantic salmon (Salmo salar L.) and fish cultural characteristics of such sperm. J. Fish Biol., 18: $1-18$.

Knutsson, S., 1979. Factors affecting the parr-smolt transformation in Atlantic salmon. I.C.E.S. $1979 / \mathrm{M} 2$, pp. 1-24.

Larsson, P-O, and Svensson, K.M., 1974. Studies on the possible influence of early maturity on grilse frequency by means of tagging experiments in the River Lule. I.C.E.S. CM 1974/M28, pp. 1-5.

Le Bail, P.Y. and Breton, B., 1981. Rapid determination of the sex of puberal salmonid fish by a technique of immunoagglutination. Aquaculture, 22: 367-375.

Le Bail, P.Y., Breton, B. and Maisse, G., 1981. Detection des femelles de salmonides en vitellogenese. 1. Description de la methode et mise en oeuvre pratique. Bull. Fr. Piscic., 283: 79--88.

Lee, R.L.G. and Power, G., 1976. Atlantic salmon (Salmo salar) of the Leaf River, Ungava Bay. J. Fish. Res. Board Can., 33: 2616-2621.

Leyzerovich, K.A., 1973. Dwarf males in hatchery propagation of Atlantic salmon. J. Ichthyol., 13: 382-392.

Lundqvist, H., 1983. Precocious sexual maturation and smolting in Baltic salmon (Salmo salar L.). Photoperiodic synchronisation and adaptive significance of annual biological cycles. Ph.D. Thesis, Umea University, Sweden, $75 \mathrm{pp}$.

Maisse, G. and Baglinière, J.L., 1983. Mise en évidence d'une marque de fraie dans la phase eau douce des ecailles de saumon atlantique du Massif Armoricain. I.C.E.S. CM 1983/M28, pp. 1-7.

Mills, D.H., 1971. Salmon and Trout. Oliver and Boyd, Edinburgh, 351 pp.

Mitans, A.R., 1973. Dwarf males and the sex structure of a Baltic salmon (Salmo salar L.) population. J. Ich thyol., 13: 192-197.

Murphy, T., 1981. Studies on precocious maturity in artificially reared 1+ Atlantic salmon parr Salmo salar L. Fish. Manage., 12:113-114.

Myers, R., 1983. Evolutionary change in the proportion of precocious parr and its effect on yield in Atlantic salmon. I.C.E.S. CM 1983/M13, pp. 1-16. 
Naevdal, G., 1983. Genetic factors in connection with age at maturation. Aquaculture, 33: 97-106.

Orton, J.H., Jones, J.W. and King, G.M., 1938. The male sexual stage in salmon parr (Salmo salar L. juv.). Proc. R. Soc. B, 125: 103-114.

Osterdahl, L., 1969. The smolt run of a small Swedish river. In: Symposium on Salmon and Trout in Streams. H.R. MacMillan Lectures in Fisheries, Univ. of British Columbia, Vancouver, Canada, pp. 205-215.

Pedley, R.B. and Jones, J.W., 1978. Growth and survival of Atlantic salmon (Salmo salar) in Llyn Dwythwch, North Wales. Freshwater Biol., 8: 423-431.

Prouzet, P., 1981. Observation d'une femelle de tacon de saumon atlantique (Salmo salar L.) parvenue à maturité sexuelle en rivière. Bull. Fr. Piscic., 282: 16-19.

Prouzet, P. and Jezequel, M., 1983. Caracteristiques des populations de saumon atlantique (Salmo salar L.) capturées à la ligne sur l'Elorn (rivière de Bretagne Nord) durant la période 1974-1981. Bull. Fr. Piscic., 289: 91-111.

Regan, C.T., 1938. Cited in Fontaine and Vibert, 1950.

Saunders, R.L., Henderson, E.B. and Glebe, B.D., 1982. Precocious maturation and smoltification in Atlantic salmon (Salmo salar). Aquaculture, 28: 211-229.

Schaffer, W.M. and Elson, P.F., 1975. The adaptive significance of variations in life history among local populations of Atlantic salmon in North America. Ecology, 56: $577-590$.

Shaw, J., 1836. An account of some experiments and observations on the parr and the ova of the salmon, proving the parr to be the young of the salmon. The Edinburgh New Philosophical Journal, 21: 99-111.

Solomon, D.J. and Child, A.R., 1978. Identification of juvenile natural hybrids between Atlantic salmon (Salmo salar L.) and trout (Salmo trutta L.). J. Fish Biol., 12: 499501.

Southern, R., 1933. Cited in Jones, 1949.

Symons, P.E.K., 1979. Estimated escapement of Atlantic salmon (Salmo salar) for maximum smolt production in rivers of different productivity. J. Fish. Res. Board Can., 36: 132-140.

Tchernavin, V., 1938. Cited in Fontaine and Vibert, 1950.

Thorpe, J.E. and Morgan, R.I.G., 1980. Growth-rate and smolting-rate of progeny of Atlantic salmon parr, Salmo salar L. J. Fish Biol., 17: 451-460.

Thorpe, J.E., Morgan, R.I.G., Ottaway, E.M. and Miles, M.S., 1980. Time of divergence of growth groups between potential $1+$ and 2+ smolts among sibling Atlantic salmon. J. Fish Biol., 17: 13-21.

Thorpe, J.E., Talbot, C. and Villarreal, C.A., 1982. Bimodality of growth and smolting in Atlantic salmon, Salmo salar L. Aquaculture, 28: 123-132.

Thorpe, J.E., Morgan, R.I.G., Talbot, C. and Miles, M.S., 1983. Inheritance of developmental rates in Atlantic salmon, Salmo salar L. Aquaculture, 33: 119-128.

Vibert, R., 1950. Recherches sur le saumon de l'Adour (Salmo salar, Linné) (ages, croissance, cycle génétique, races) 1942-1948. Ann. Stat. Cent. Hydrobiol. Appl., 13: $1-149$.

White, H.C. and Medcof, J.C., 1968. Atlantic salmon scales as records of spawning history. J. Fish. Res. Board Can., 25: 2439-2441. 